\title{
戸別合併浄化槽処理水における重金属の濃度実態と 処理水灌溉利用時の安全性
}

Heavy Metal Concentrations in Reclaimed Wastewater in Combined Household Wastewater Treatment Facilities for Individual Houses and Its Safety under Reusing the Reclaimed Wastewater for Irrigation

\author{
治多伸介* 櫻井雄二* \\ Shinsuke HARUTA* Yuji SAKURAI* \\ ( *愛媛大学農学部) \\ ( ${ }^{*}$ Faculty of Agriculture, Ehime University)
}

\section{I はじめに}

し尿と生活雑排水を処理するために，各家庭に設置さ れる戸別合併浄化槽は，集合処理方式である農業集落排 水施設よりも，1家庭あたりの建設費が安価で設置が迅 速である等の利点を有する。そのため, 戸別合併浄化槽 の導入を推進している農村地域は多い。

戸別合併浄化槽の処理水は，近隣の水路や河川に放流 されることが多く，その処理水質に関する情報は，戸別 合併浄化槽の導入に伴う農村地域の水質変化の予測や評 価を行うために極めて重要である。一方，戸別合併浄化 槽の処理水は, 今後の水資源枯渇に備えて, 再利用用途

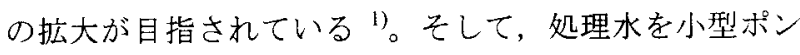
プで送水するなどして，家庭の庭の樹木，花茾，菜園に 灌溉利用するといった処理水の再利用が検討されている 2)。このような好理水利用を安全かつ効果的に行うため にも，処理水質に関する情報は極めて有用である。

これらのことから，戸別合併浄化槽の処理水質実態に ついては、これまでも研究が行われてきた。しかし，こ れまでの主な研究 233445) は, SS, BOD, COD, 窒素, り ン，塩類に関するものである。そして，家庭の庭に灌溉 水として処理水を再利用した場合に，植物に好ましくな い影響を与えたり，作物を介してそれを食した人体に悪 影響を与えることが危惧される「重金属」の調査は不十 分である。生活排水には，食品，医療品，紙，洗剂，化 粧品などに由来する重金属が含まれる ${ }^{6}$ が，戸別合併浄 化槽処理水の重金属濃度に関する研究は見あたらない。

以上より，本報では重金属を対象として，農村地域の 戸別合併浄化槽処理水の濃度実態を検討し, その処理水
を家庭の庭に灌溉利用した場合の安全性を明らかにする ことを目的とした。そして，愛媛県 I 市 M 地区の 34 基 の净化槽を調查し，戸別合併浄化槽処理水の利用が，植 物生育やそれを食した人体に及ぼす安全性を検討した。

\section{II 研究方法}

本研究に関する調査は, 平成 4 年以降, 戸別合併浄化 槽が積極的に導入されている愛媛県 $I$ 市 $M$ 地区で行った。 すなわち，M 地区の戸別合併浄化槽 70 基のうち, 調查 訪問時に在宅があり,調查許可が得られた 34 基を調査対 象とした。そして，サンプリング時間や矅日は固定せず にランダムな時閒と曜日にスポット採水を行った。また， 水温の比較的低い時期と高い時期に，同じ浄化槽で 1 回 ずつ採水を行った。このようにしたのは，各浄化槽の処 理水質に, 日内変動や季節変動があった場合においても, このような採水をすれば， M 地区における処理水濃度 分布の大略を知ることが可能になると考えたためである。 調查期間は, 平成 19 年 2 月 13 日-3月 11 日と平成 19 年 9 月 26 日-10月 30 日の 2 期間とし， 34 基の浄化槽で, 各々の期閒に 1 回ずつ処理水を採水した $(\mathrm{n}=68)$ 。採水は, 塩素消毒後の放流水に対して実施した。

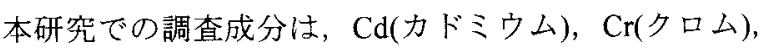

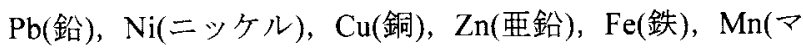
ンガン)の 8 成分とした。水質分析は下水試験方法 ${ }^{7}$ に準 拠して行った。すなわち, 影濁態上溶存態を合わせた全 量分析は, 採取した試料に対して, 硝酸・塩酸を添加し て加熱分解を行った後，その試料を ICP-MS(Varian 820-MS)で分析した。溶存態については, 試料採取後, 
現場で速やかに孔径 $0.5 \mu \mathrm{m}$ のテフロン製フィルターで濾 過した試料に対して，硝酸・塩酸を添加し，ICP-MS で 分析した。眯濁態の濃度は, 全量の分析值から, 溶存態 の分析值を差し引き計算して求めた。なお，分析の定量 下限值は，いずれの元素も $0.5 \mu \mathrm{g} \cdot \mathrm{L}^{-1}$ である。重金属には， 上記 8 成分以外にも，As(ヒ素), $\mathrm{Hg}$ (水銀)等も存在する が，今回は分析対象としなかった。今回対象とした 8 成 分は，全てが硝酸・塩酸分解に適した元素であり，同じ 分解手順を経て ICP-MS で分析できる。しかし，それ以 外の元素については, 別の分解条件や分析機器が必要で あり，8 成分と同時に分析するためには多大な労力を要 する。従って, 今回の研究では, 先ず, 硝酸・塩酸分解 と ICP-MS で対志できる 8 成分の検討を行うこととした。 As, $\mathrm{Hg}$ 等の検討は，今後の課題としたい。

浄化槽の処理方式 - 型式 - 管理状況は, I 市の净化槽 台帳で把握し，実使用人数は住民基本台帳から調查し， 水道使用量は, I 市の水道記録から調べた。水道水質の 把握は, 水道統計 ${ }^{8)}$ で行った。

\section{III 結果と考察}

\section{1 戸別合併净化槽の稼働状況}

(1) 処理方式

調查した浄化槽 34 基の好理方式・基数・設置年・製造 会社と法令上の処理水質を表 1 に示す。表 1 のように， 34 基の大部分(約 8 割)は「嫌気性濾床接触曝気方式」で あった。「嫌気滤床接触嚗気方式」の浄化槽は, 全て建設 省告示第 1292 号第 1 第二号に該当する処理方式で，「嫌 気滤床及び生物滤過を組み合わせた方式」と「流量調整 型嫌気滤床担体流動生物濾過循環方式」は，建築基淮法 施行令 35 条第 1 項の大臣認定の処理方式であった。

ただし，「嫌気濾床及び生物滤過を組み合わせた方式」 と「流量調整型嫌気滤床担体流動生物濾過循環方式」は 基数が少なかったためか，「嫌気性濾床接触曝気方式」と， 処理水の重金属濃度が異なる傾向は明確とならなかった。 そのため，以下においては，処理方式による区別はせず に調査結果を示している。

(2) 人槽と実使用率

調査した埩化槽は $5-10$ 人槽で, 実使用人数は 1-7人で あった。それにより，実使用率(実使用人数 $\div$ 人槽 $\times 100$ )
は 20-100\%となり，平均値は $48 \%$ であった。

（3）水道使用量上水道水質

$\mathrm{M}$ 地区において, 各家庭独自の地下水を生活用水に利 用している家庭はなかった。従って, 各浄化槽の処理水 量は「各家庭の水道使用量」とほほ同量と考えられた。 平成 19 年 2-3 月と9-10月における 1 人あたりの水道使 用量の平均値は, 各々 $252 \mathrm{~L} \cdot 人^{-1} \cdot \mathrm{d}^{-1}$ と $249 \mathrm{~L} \cdot$ 人 $^{-1} \cdot \mathrm{d}^{-1}$ であ り，差は殆どなかった。日本における1人あたりの排出 污水量の平均的な值は $250 \mathrm{~L} \cdot 人^{-1} \cdot \mathrm{d}^{-1}$ 4)であり，調査した 浄化槽の状況と類似していた。

「調査地区の水道水中の重金属濃度」は，処理水中の 重金属濃度に影響する可能性がある。水道統計(平成 19 年度版 $)^{8}$ に示された $\mathrm{M}$ 地区の水道水質成分の年間平均 值は, $\mathrm{Cd}\left(1 \mu \mathrm{g} \cdot \mathrm{L}^{-1}\right.$ 末満 $), \operatorname{Cr}\left(5 \mu \mathrm{g} \cdot \mathrm{L}^{-1}\right.$ 末満 $), \mathrm{Pb}\left(1 \mu \mathrm{g} \cdot \mathrm{L}^{-1}\right.$ 未 満), $\mathrm{Ni}\left(2 \mu \mathrm{g} \cdot \mathrm{L}^{-1}\right), \mathrm{Cu}\left(10 \mu \mathrm{g} \cdot \mathrm{L}^{-1}\right.$ 未満), $\mathrm{Fe}\left(30 \mu \mathrm{g} \cdot \mathrm{L}^{-1}\right.$ 未満), $\mathrm{Mn}\left(5 \mu \mathrm{g} \cdot \mathrm{L}^{-1}\right.$ 未満), $\mathrm{Zn}\left(10 \mu \mathrm{g} \cdot \mathrm{L}^{-1}\right.$ 末満 $)$ であり, 日本全国の 水道水の平均的な值であった。

なお，重金属は，水道管や蛇口からも溶出して水道水 に混入する可能性がある9)。今回調查対象とした家庭の 約 8 割は築 20 年以上であり, 老朽化した水道管や蛇口を 利用していた。ただし, それらの家庭の浄化槽処理水中 の重金属濃度が，それ以外の築年数の浅い家庭よりも高 い傾向は見られなかった。また，処理水の重金属濃度に は, 経年劣化による浄化槽本体からの重金属溶出が影響 する可能性も考えられる。ただし, 今回調査した浄化槽 の設置年数は 3 年から 15 年まで多様であったものの, 設 置年数が長い浄化槽の処理水で重金属濃度が高いという 傾向は見られなかった。以上より, 水道管, 蛇口, 浄化 槽本体の経年劣化による重金属溶出が，今回の調査結果 に及ぼした影響は大きくないと考えられた。

(4) 管理状況

浄化槽法に定められた「保守点検業者による4ケ月に 1 回以上の保守点検」は, 調查した全ての浄化槽で遵守 されていた。

\section{2 処理水質}

測定した 68 試料の処理水における重金属濃度分布は, 分析した元素毎に大きく異なった。また，植物生育に悪 影響を与える濃度や，植物を介しての人体一悪影響を及 ぼす濃度は，元素によって異なる。そのため，以下には，

表l 調査した浄化槽の処理方式・基数・設置年・製造会社・法定処理水質一覧

Table 1 Outline of Investigated Household Wastewater Treatment Facilities

\begin{tabular}{ccccc}
\hline \hline 処理方式 & 基数 & 設置年 & 製造会社 & 処理水質 \\
\hline 嫌気性濾床接触曝気方式 & 26 & $\mathrm{H} 4-\mathrm{H} 16$ & $\mathrm{~A} \cdot \mathrm{B} \cdot \mathrm{D} \cdot \mathrm{I}$ 社 & $\mathrm{BOD} 20 \mathrm{mg} \cdot \mathrm{L}^{-1} \mathrm{~W}$ \\
嫌気滤床及び生物滤過を組み合わせた方式 & 6 & $\mathrm{H} 10-\mathrm{H} 17$ & $\mathrm{H}$ 社 & $\mathrm{BOD} 20 \mathrm{mg} \cdot \mathrm{L}^{-1} \mathrm{~W}$ \\
流量調整型嫌気滤床担体流動生物濾過循環方式 & 2 & $\mathrm{H} 16$ & $\mathrm{D}$ 社 & $\mathrm{BOD} \cdot \mathrm{T}-\mathrm{N} 20 \mathrm{mg} \cdot \mathrm{L}^{-1}$ 以下 \\
\hline
\end{tabular}


元素每の測定結果と，安全性江対寸る考察を順次示す。 なお，特に示さない限り，提示する濃度は，䀣濁態と溶 存態を合わせた全量の濃度である。また, 以下の安全性 の検討では，灌溉水に対する基準 ${ }^{10) 111}$ だけでなく，水道 水質基淮 ${ }^{12)}$ も利用する。これは，灌溉水基準よりも水道 水質基準の方が厳しい元素が多く存在するため, 処理水 の灌溉水としての利用考考える場合でも，水道水質基準 も利用することで，より厳しく安全性を評価できると考 えたためである。

(1) $\mathrm{Cd}$

$\mathrm{Cd}$ は, 腎臓障害や骨軟化症等の人体への強い悪影響を 与える ${ }^{12}$ ため，人八の安全性には特に注意が必要である。

今回行った分析では, Cdは, 全ての試料で検出されな かった。今回の分析に用いた ICP-MS 法の定量限界は $0.5 \mu \mathrm{g} \cdot \mathrm{L}^{-1}$ である。従って, 今回調查した処理水中の $\mathrm{Cd}$ は $0.5 \mu \mathrm{g} \cdot \mathrm{L}^{-1}$ 以下であり，水道水質基準 $\left(10 \mu \mathrm{g} \cdot \mathrm{L}^{-1}\right) の 1 / 10$ より低いといら極めて低濃度であったことが分かった。 また，土壌への重金属蓄積の影響も加味して，作物の人 体一の悪影響が生じないように決められた米国環境保護 局(U.S.EPA) 0 農業灌溉水 $の$ 基淮值 ${ }^{10)}$ (以下，EPA 灌溉基 準)や日本の水質障害対策事業に倸る農業用水基準 ${ }^{11}$ (以 下，水質障害対策基準)も $10 \mu \mathrm{g} \cdot \mathrm{L}^{-1}$ であり，今回の処理水 中の濃度は，それらを大きく下回っていた。

以上より，今回調查した処理水中の Cd は, 処理水を 灌溊水として再利用しても問題のない濃度であると考え られた。

(2) $\mathrm{Cr}$

Cr は，発ガンや肝炎等の人体への毒性が危惧される元 素であり，特に毒性が強いのは六価の $\mathrm{Cr}$ である ${ }^{12) 。 一 ~}$ 方，植物に対する毒性は明確となっていない10)。

今回の測定では, Crは 1 試料のみが $1.0 \mu \mathrm{g} \cdot \mathrm{L}^{-1}$ であり， それ以外の試料では定量下限值の $0.5 \mu \mathrm{g} \cdot \mathrm{L}^{-1}$ 以下であっ た。EPA 灌溉基準は $100 \mu \mathrm{g} \cdot \mathrm{L}^{-1}$ であり，水質障害対策基 準と水道水質基準は六価 $\mathrm{Cr}$ に対して，それぞれ $100 \mu \mathrm{g} \cdot$ $\mathrm{L}^{-1}$ と $50 \mu \mathrm{g} \cdot \mathrm{L}^{-1}$ となっている。今回の測定は六価だけでな $く$ ，二価・三価の Cr も含めて測定をしているが，測定值 は，いずれも各基準値の1/50か，それ以下と低かった。 以上より，Crについても，今回調査した処理水は; 灌 溉利用しても問題のない濃度と考えられた。

$(3) \mathrm{Pb} \cdot \mathrm{Ni} \cdot \mathrm{Cu} \cdot \mathrm{Zn} \cdot \mathrm{Fe} \cdot \mathrm{Mn}$

$\mathrm{Cd}, \mathrm{Cr}$ 以外の重金属は，全ての試料で ICP-MSによる 定量下限值 $\left(0.5 \mu \mathrm{g} \cdot \mathrm{L}^{-1}\right)$ 以上の濃度が検出された。また, それらの濃度には、試料によって大きな違いが見られた。 従って, Cd, Cr 以外の重金属については, 以下に単純平 均值と頻度分布を示し, 安全性老検討寸る。また, 表 2 には，各種水質基準濃度をとめて示した。
表 2 各種水質基準値の一覧

Table 2 Water Quality Criteria

\begin{tabular}{|c|c|c|c|c|}
\hline & 水道 & EPA & 水質障害 & 水稻 \\
\hline & 水質基隻 ${ }^{12)}$ & 灌潫基準 ${ }^{10)}$ & 対策基準 ${ }^{11)}$ & 水質基準 ${ }^{11}$ \\
\hline $\mathrm{Pb}$ & 10 & 5000 & 100 & - \\
\hline $\mathrm{Ni}$ & 10 (暫定) & 200 & - & - \\
\hline $\mathrm{Cu}$ & 1000 & 200 & - & 20 \\
\hline $\mathrm{Zn}$ & 1000 & 2000 & - & 500 \\
\hline $\mathrm{Fe}$ & 300 & 5000 & - & - \\
\hline $\mathrm{Mn}$ & 50 & 200 & - & - \\
\hline
\end{tabular}

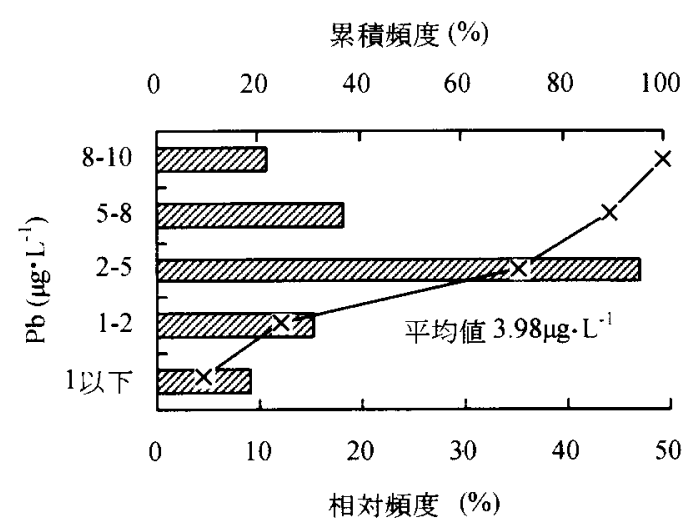

図 1 処理水中の $\mathrm{Pb}$ 濃度の相対頻度上累積頻度 Fig.1 Pb Concentrations in Reclaimed Wastewater

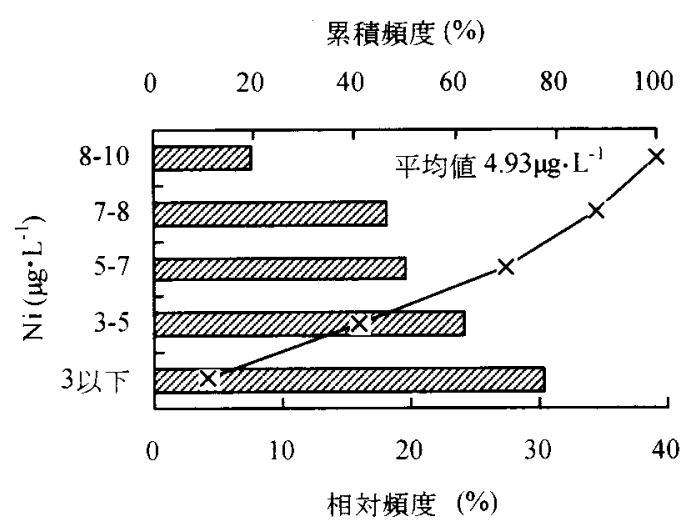

図 2 処理水中の $\mathrm{Ni}$ 濃度の相対頻度と累積頻度 Fig.2 Ni Concentrations in Reclaimed Wastewater

(i) $\mathrm{Pb} \cdot \mathrm{Ni}$

$\mathrm{Pb}$ と $\mathrm{Ni}$ については, 水道水質基準において, 人の健 康に配慮して，Cd と同じ $10 \mu \mathrm{g} \cdot \mathrm{L}^{-1}$ 以下という低い濃度 の基隻值が設けられている。一方，図1，2には，それぞ れ今回測定した処理水中の $\mathrm{Pb}$ と $\mathrm{Ni}$ の濃度頻度分布を, 単純平均値とともに示した。

図 1，2 より， $\mathrm{Pb} ， \mathrm{Ni} の$ 単純平均值はそれぞれ $3.98 \mu \mathrm{g} \cdot$ $\mathrm{L}^{-1}$ と $4.93 \mu \mathrm{g} \cdot \mathrm{L}^{-1}$ で，水道水質基準值を大きく下回ってい た。また，最大值も， Pb, Ni のいずれもが $10 \mu \mathrm{g} \cdot \mathrm{L}^{-1}$ 以下 


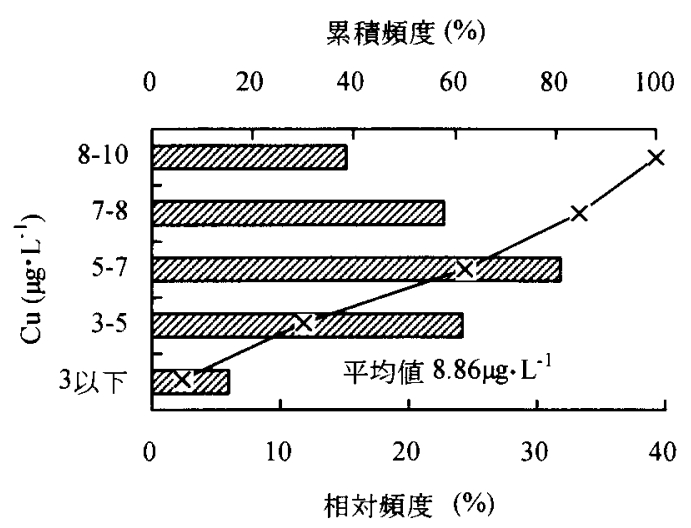

図 3 処理水中の $\mathrm{Cu}$ 濃度の相対頻度と累積頻度 Fig. $3 \mathrm{Cu}$ Concentrations in Reclaimed Wastewater

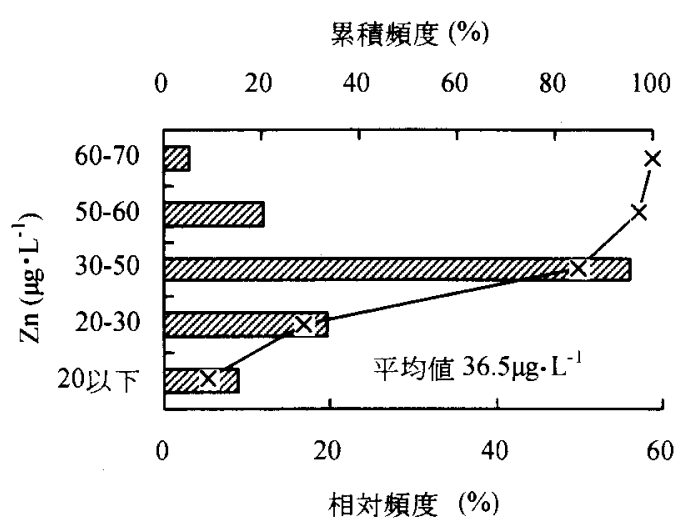

図 4 処理水中の $\mathrm{Zn}$ 濃度の相対頻度と累積頻度 Fig. $4 \mathrm{Zn}$ Concentrations in Reclaimed Wastewater

であり，水道水質基淮以下であった。一方，EPA 灌溉基 準や水質障害対策基準は，水道水質基準よりもかなり高 く，それらに対しては，Pb， Ni はともに処理水濃度は最 大值でも $1 / 10$ 以下と，基準值を大きく下回っていた。

以上より, $\mathrm{Pb}$ と $\mathrm{Ni}$ についても, 今回調查した処理水 は，灌溉利用に問題のない薸度であったと考えられた。 (ii ) $\mathrm{Cu} \cdot \mathrm{Zn}$

$\mathrm{Cu}$ と Zn は，水稲の生育に影響を与えやすく，人体一 の影響度は低い12)ために，農業(水稲)用水水質基淮(以下， 水稲水質基淮)に法, 水道水質基準よりも低い基準值が設 定されている。

図 3, 4 には, 処理水中の $\mathrm{Cu} と \mathrm{Zn}$ の頻度分布を示し た。 $\mathrm{Cu}, \mathrm{Zn}$ の濃度は，最大值でもそれぞれ $10 \mu \mathrm{g} \cdot \mathrm{L}^{-1}$ 以 下， $70 \mu \mathrm{g} \cdot \mathrm{L}^{-1}$ 以下であり，水稲水質基準よりかなり低か った。水稲が家庭の庭で栽培されることは，まず無いと 考えられるが，水稲は， $\mathrm{Cu}$ と Zn に敏感な作物の代表で ある。それゆえ，今回の結果は，Cu と Zn については， 戸別合併净化槽処理水の作物生育一の安全性流かなり高 いことを示している。一方，水道水質基準やEPA 灌溉基 淮に比較すると, $\mathrm{Cu}$ と $\mathrm{Zn}$ の濃度注最大值でも $1 / 20$ 以下 と基準値を大きく下回っていた。

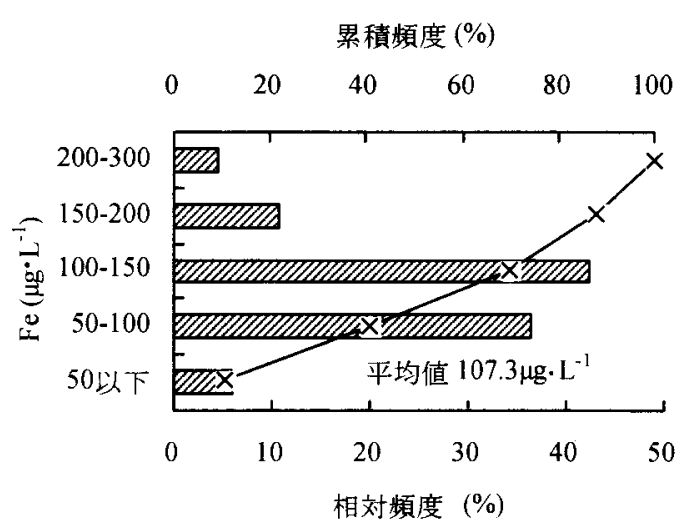

困 5 処理水中の $\mathrm{Fe}$ 濃度の相対頻度と累積頻度 Fig. 5 Fe Concentrations in Reclaimed Wastewater

累積頻度 $(\%)$

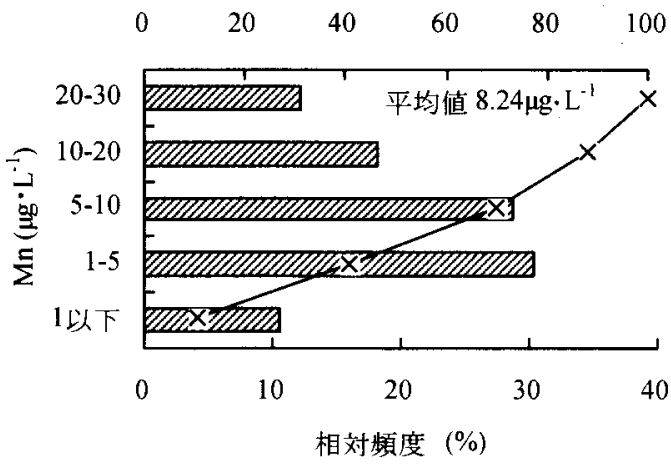

図 6 処理水中の Mn 濃度の相対頻度之累積頻度 Fig. 6 Mn Concentrations in Reclaimed Wastewater

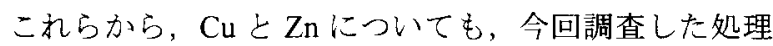
水は, 灌溉利用に問題のない濃度であったと考えられた。 (iii) $\mathrm{Fe} \cdot \mathrm{Mn}$

$\mathrm{Fe}$ と $\mathrm{Mn}$ の人体への毒性は低く，水道水質基準は，着 色防止の観点から決められている ${ }^{12) 。}$ 。従って，人体に悪 影響が生じる濃度は，水道水質基準値よりもかなり高い。

図 5, 6 には，処理水中の $\mathrm{Fe}$ と $\mathrm{Mn}$ の濃度分布を示し た。図 5，6より， $\mathrm{Fe}$ と $\mathrm{Mn}$ の単純平均值(それぞれ， $\left.107.3 \mu \mathrm{g} \cdot \mathrm{L}^{-1}, 8.24 \mu \mathrm{g} \cdot \mathrm{L}^{-1}\right)$ は，水道水質基準值(それぞれ， $\left.300 \mu \mathrm{g} \cdot \mathrm{L}^{-1}, \quad 50 \mu \mathrm{g} \cdot \mathrm{L}^{-1}\right)$ を大きく下回っていた。また， $\mathrm{Fe}$ と $\mathrm{Mn}$ の最大值も水道水質基準より低く, EPAの灌溉基 準に比較すると, $\mathrm{Fe}$ は 1/20 以下, $\mathrm{Mn}$ は 1/5 以下とかな り低濃度であった。

以上より, 調查した処理水は, $\mathrm{Fe}$ と $\mathrm{Mn}$ についても, 灌溉利用に問題のある濃度ではなかったと判断すること ができた。

\section{3 処理水の重金属湿度に影響を及ぼす要因}

前節に示したように，今回調查した処理水の重金属濃 度は，どの成分についても，各種基準值以下であった。 ただし，基淮值以下であっても，より低濃度の水を排出 


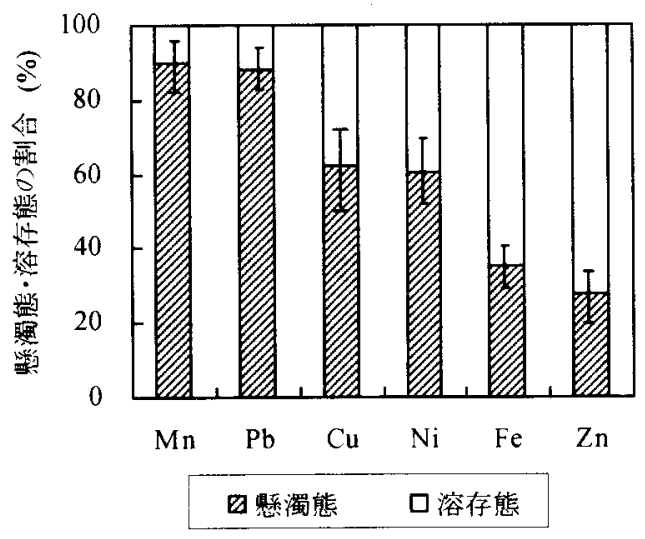

図 7 重金属成分毎の懸濁態と溶存態の存在率 (縦棒は標準偏差)

Fig.7 Percentage of Suspended and Dissolved Matter in Each Heavy Metal

することは，更なるリスク低隇に䔝がると考えられる。 そのため, 処理水の重金属濃度に影響する因子を明らか にし，それに留意した対応を行っていくことはより適 切な処理水利用環境を保つために大切と考えられる。ま たそれは，重金属濃度が予想以上に高まることを防ぐリ スク管理にも槃がる。そこで，本節では，処理水質に及 ぼす影響因子を検討することとした。

(i) 懸濁成分の影響

下水処理施設の污泥には重金属が含まれ，今回調査し た処理水中にも，污泥は䀣濁成分(SS) として混入し，乙 の濃度は高い場合には $41.3 \mathrm{mg} \cdot \mathrm{L}^{-1}$ にも達していた。そこ で，その懸濁成分が処理水質に大きな影響を及ぼしてい るかどうかを検討するために，図７に処理水中の重金属 の懸濁態と溶存態の割合の平均值と標淮偏差を示した。

図 7 より，懸濁熊が占める割合は元素毎に異なるもの の, 多くの元素で懸濁態の割合は大きく, $\mathrm{Mn}$ と $\mathrm{Pb}$ は $90 \%$ 程度が， $\mathrm{Cu}$ と $\mathrm{Ni}$ では $60 \%$ 程度が懸濁態であった。この 結果は，重金属が低濃度の処理水を得るためには，懸濁 成分を流出させない管理が重要であることを示している。 また，懸濁成分の流出抑制効果が発現しやすいのは, Mn, $\mathrm{Pb}, \mathrm{Cu}, \mathrm{Ni}$ であることを示している。

(ii) 時間的な変動

今回の調查では，処理水中の重金属含有の季節変動状 況を見るために，同じ浄化槽について 2-3 月(処理水平均 水温 $15.5^{\circ} \mathrm{C}$ ) と $9-10$ 月(处理水平均水温 $24.8^{\circ} \mathrm{C}$ ) $の 2$ 回の調 查を行った。その 2 回の調査結果の関係性の例として, $\mathrm{Zn}$ の結果を図 8 に示す。図 8 のように，2回の $\mathrm{Zn}$ 調查 結果に相関は見られず, その傾向は, 他のいずれの元素 についても同様であった。ただし，表 3 に示したように， いずれの元素についても，9-10月と2-3 月の最小值と最 大值が大きく異なる傾向はなか力た。このことは，各合

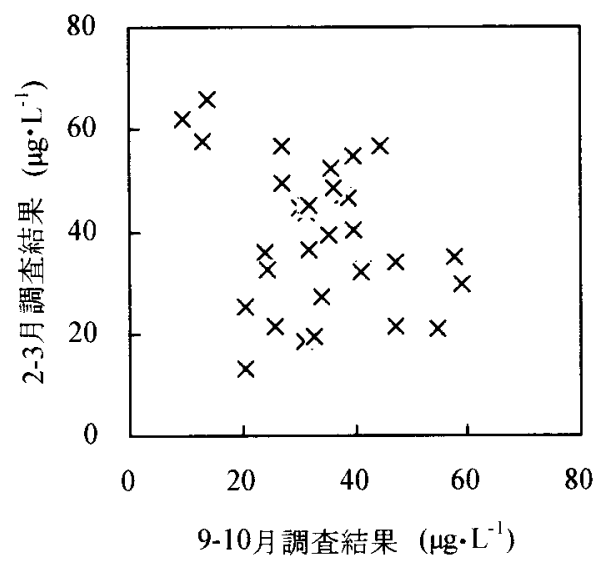

図 82 回の調査濃度の関係 ( $\mathrm{Zn}$ 濃度の例) Fig. 8 Relations of $\mathrm{Zn}$ Concentrations between Two Seasons

表 3 重金属濃度の最小值・最大值 Table 3 Maximum and Minimum concentrations in two seasons

\begin{tabular}{ccccc}
\hline \hline & \multicolumn{2}{c}{ 最小濃度 } & \multicolumn{2}{c}{ 最大濃度 } \\
& $2-3$ 月 & $9-10$ 月 & 2-3月 & $9-10$ 月 \\
\hline $\mathrm{Pb}$ & 0.68 & 0.51 & 8.70 & 7.59 \\
$\mathrm{Ni}$ & 1.04 & 2.76 & 9.35 & 9.81 \\
$\mathrm{Cu}$ & 1.67 & 3.93 & 19.27 & 18.60 \\
$\mathrm{Zn}$ & 12.94 & 9.50 & 65.71 & 58.84 \\
$\mathrm{Fe}$ & 39.36 & 45.60 & 184.86 & 205.01 \\
$\mathrm{Mn}$ & 2.12 & 2.46 & 6.62 & 6.65 \\
\hline & & & \multicolumn{2}{c}{ 単位 $: \mu \mathrm{g} \cdot \mathrm{L}^{-1}$}
\end{tabular}

併浄化槽での重金属濃度は時期によって大きく変動した ものの, $\mathrm{M}$ 地区の合併浄化槽全体で見た場合の処理水の 濃度分布範囲は，比較的安定していたことを示している。 流入排水中の重金属は, 浄化槽内の微生物に吸着や吸 収されたり，懸濁態で沈殿し，污泥として除去される ${ }^{13)}$ 。 その一方で, 浄化槽内に貯留された污泥からは, 重金属 が再溶出して水中に回帰する場合もある。このような重 金属の除去能力や回㷌状況に影響する可能性のある浄化 槽内の DO, $\mathrm{pH}$ や污泥蓄積状況は, 調査した浄化槽で多 様であった。具体的には, 調査日以前の污泥引き抜き日 から調査日までの経過日数は 7 日〜30 ケ月，曝気槽内水 の DO 4 0.7-9.0 $\mathrm{mg} \cdot \mathrm{L}^{-1}, \mathrm{pH}$ は 5.6-7.8, 嫌気槽内水の DO は 0.0-2.0 $\mathrm{mg} \cdot \mathrm{L}^{-1}, \mathrm{pH}$ は 6.5-8.8 の範囲に幅広く分布し, 2-3 月と9-10月の調查での分布範囲は類似していた。こ のように，今回の調查は，限られた期間と数の調査では あるものの，多様な净化槽を調查している。そのため， 今回得られた重金属濃度の分布状況は，M地区の合併浄 化槽の水質状況をかなり良好に表していると考えられる。 なお，いずれの埩化槽でも，2-3月と9-10月に，曝気 量や返送水量, 使用人数等は変化して抢らず, それらが 
両期間の間での濃度変動の原因とは考えられなかった。 2-3 月と 9-10月の濃度変動は, 各家庭の重金属排出量の 変動が原因とも考えられるが，今回の調査ではそれを明 確にすることはできなかった。重金属濃度の時間的な変 動原因を明確にすることは，今後の課題である。

\section{IV まとめ}

本研究では，愛媛県 I 市 M 地区の戸別合併浄化槽 34 基について，平成 19 年 2-3 月と9-10月の期間にそれぞ れ 1 回ずつ処理水の採水を行った。そして，その全 68 試料の重金属濃度を ICP-MS(定量下限值 $0.5 \mu \mathrm{g} \cdot \mathrm{L}^{-1}$ )で分 析した。その結果をまとめると以下のようになる。 1)Cd は，全試料が定量下限值以下で， $\mathrm{Cr}$ は，1 試料のみ が $1.0 \mu \mathrm{g} \cdot \mathrm{L}^{-1}$ で，それ以外は定量下限值以下であった。 2) $\mathrm{Pb}, \mathrm{Ni}, \mathrm{Cu}, \mathrm{Zn}, \mathrm{Fe}, \mathrm{Mn}$ は，全試料で定量下限値以 上で，濃度分布は元素毎に異なっていた。単純平均濃度 は Pb $3.98 \mu \mathrm{g} \cdot \mathrm{L}^{-1}$, Ni $4.93 \mu \mathrm{g} \cdot \mathrm{L}^{-1}$, Cu $8.86 \mu \mathrm{g} \cdot \mathrm{L}^{-1}, \mathrm{Zn} 36.5 \mu \mathrm{g} \cdot$ $\mathrm{L}^{-1}$, Fe $107.3 \mu \mathrm{g} \cdot \mathrm{L}^{-1}, \mathrm{Mn} 8.24 \mu \mathrm{g} \cdot \mathrm{L}^{-1}$ であった。 3) $\mathrm{Pb}, \mathrm{Ni}, \mathrm{Cu}, \mathrm{Zn}, \mathrm{Fe}, \mathrm{Mn}$ の濃度は，測定された最大 値であっても，全て水道水質基準值以下であった。また， 米国環境保護局の灌溉水基準值，日本の農業(水稲)用水 水質基準値，水質障害対策事業に関わる農業用水水質基 隻值も全て下回っていた。

4) $\mathrm{Mn}, \mathrm{Pb}, \mathrm{Cu}, \mathrm{Ni}$ では賏濁態の割合が大きく，平均で

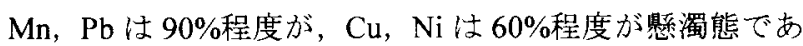
った。

5)2-3 月と 9-10 月の各成分の濃度間 $(n=34) に$ 相関はなか ったものの，両者の濃度分布範囲は，重金属の種類によ らず大差はなかった。

これらから，処理水を各家庭の庭に灌溉水として利用 した場合，処理水中の $\mathrm{Cd}, \mathrm{Cr}, \mathrm{Pb}, \mathrm{Ni}, \mathrm{Cu}, \mathrm{Zn}, \mathrm{Fe}$, Mn によって，植物生肙や，それを食した人に対する悪 影響が生じる可能性は極めて低いと考えられた。また， 処理水の重金属濃度を低下させるには，㲘濁成分を流出
させない留意が重要であることが示唆された。

以上のように，本研究は，日本ではじめて，戸別合併 浄化槽処理水中の重金属含有状況を詳細に明らかにし， 処理水の灌溉利用面での安全性の高さを指摘した。

\section{引用文献}

1)山海俊弘(1998)：2.3.3 今後の展望および課題(稲森悠平編,『生 活排水対策』)，産業用水調查会，東京，64-68.

2)治多伸介・櫻井雄二(2010) : 戸別合併浄化槽処理水中の塩類濃 度実態上処理水利用時の留意点, 農村計画学会誌, 28 巻論文特 集号，357-362.

3)藤村萧子(2006): 生活排水の負荷原単位と各種净化槽による排 出負荷, 用水上廃水, 48(5), 64-70.

4)治多伸介・櫻井雄二(2007)：農村地域における戸別合併浄化槽 処理水質の害態解明，農村計画学会誌, 26 巻論文特集号, 215-220。 5)治多伸介・櫻井雄二(2009): 農村地域におけ万別合併浄化槽 処理水質の季節変動特性，農村計画学会誌， 27 巻論文特集号, 223-238.

6)田井慎吾 - 岡田光正 - 須藤隆一(1980):生活廃水污泥中の重金 属の由来について，国立公害研究所研究報告，14，203-211。 7)建設省都市局下水道部 - 厚生省生活衛生局水道環境部監修 （1997）：下水試験方法 下巻，(社)日本下水道協会，東京 8)(社) 日本水道協会編(2008): 水道統計「平成 19 年度」第 90 号, (社)日本水道協会, 東京。

9)森忠洋・森山清・荒屋敷秀俊 - 森 泰 - 斎藤 寞 - 中野篤 俊・茅野充男(1987)：家庭加放下水一排出される重金属の原単 位，水質污濁研究，10(7)，29-36

10)Asano, T., Burton, F.L., Leverenz, H.L., Tsuchihashi, R., and Tchobanoglous, G.(2007): Water Reuse, Mcgraw-Hill, New York, 966-968.

11)水質環境学編集委員会著(1998):清らかな水のためのサイエ ンス-水質環境学-, (社)農業士木学会, 東京,19-24.

12)日本環境管理学会編(2009):改訂 4 版 水道水質基準ガイドブ ック，丸善，東京

13)川自幸徳・坪井博和・森田弘昭(2003): 重金属の污泥八の蓄積 㧍よび存在形態に関する研究，下水道協会誌，40(486), 127-139.

Summary The reclaimed wastewater quality in 34 treatment facilities of combined household wastewater for individual houses were investigated in the rural area in Ehime Prefecture, in Japan. The mean concentrations of $\mathrm{Cd}, \mathrm{Cr}, \mathrm{Pb}, \mathrm{Ni}, \mathrm{Cu}, \mathrm{Zn}, \mathrm{Fe}, \mathrm{Mn}$ were $<0.5 \mu \mathrm{g} \cdot \mathrm{L}^{-1},<0.5 \mu \mathrm{g} \cdot \mathrm{L}^{-1}, 3.98 \mu \mathrm{g} \cdot \mathrm{L}^{-1}, 4.93 \mu \mathrm{g} \cdot \mathrm{L}^{-1}, 8.86 \mu \mathrm{g} \cdot \mathrm{L}^{-1}, 36.5 \mu \mathrm{g} \cdot \mathrm{L}^{-1}, 107.3 \mu \mathrm{g} \cdot \mathrm{L}^{-1}, 8.24 \mu \mathrm{g} \cdot \mathrm{L}^{-1}$, respectively. The values and the distribution of the concentrations showed that the heavy metals $(\mathrm{Cd}, \mathrm{Cr}, \mathrm{Pb}, \mathrm{Ni}, \mathrm{Cu}, \mathrm{Zn}, \mathrm{Fe}, \mathrm{Mn}$ ) concentrations in the reclaimed wastewater were low enough to keep good plants growth and human health. Therefore, the risk of irrigating the reclaimed wastewater for individual gardens must be low.

Keywords Reclaimed Wastewater Reuse, Heavy Metal, Combined Household Wastewater Treatment Facility 